\title{
Students as Stakeholders in the Policy \\ Context of the European Standards \\ and Guidelines for Quality Assurance \\ in Higher Education Institutions
}

\author{
Frauke Logermann and Liudvika Leišytė
}

\section{Introduction}

Since the early 1990s, the importance of quality assurance in higher education (HE) has steadily increased on the European higher education policy agenda (ESU 2010). Especially the Bologna Process, launched in 1999, supported the development of common European quality principles in higher education, as the introduction of a common three-cycle degree structure urged the need for greater comparability in quality standards amongst European higher education institutions (HEIs) (Corbett 2003). Moreover, in order to become the most competitive knowledge economy in the world (Lisbon Strategy 2009), Europe had to assure the high quality of its HE systems (Keeling 2006). The adoption of the European Standards and Guidelines for Quality Assurance (ESG) in 2005 was a landmark for the establishment of the European wide higher education quality standards by pan European bodies, including EUA, ESU, EURASHE and ENQA.

The ESG have drawn attention to the role of various stakeholders in ensuring the quality of higher education. Interestingly, the role of students as stakeholders in higher education institutions' HEIs internal quality assurance processes is substantially highlighted (Leisyte et al. 2013). According to the ESG (2005), a greater involvement of students in internal quality assurance will be beneficial for enhancing quality in European HE (Klemenic 2012; Murray 1997). This is in line with the studies pointing out the effects of student involvement in quality assurance of higher education (HE) (Hounsell 2007).

F. Logermann · L. Leišyte $(\bowtie)$

Zentrum für HochschulBildung, TU Dortmund, Germany

e-mail: liudvika.leisyte@tu-dortmund.de

F. Logermann

e-mail: f.logermann@student.utwente.nl

(C) The Author(s) 2015

A. Curaj et al. (eds.), The European Higher Education Area,

DOI 10.1007/978-3-319-20877-0_43 
Although student's role in HEIs' internal quality processes has been increasingly highlighted to achieve the Bologna objectives, up to date few studies have been conducted to understand how HEIs' perceive the role of students in internal quality assurance procedures (Kohoutek et al. 2013). Thus, little is known about students' real position in internal quality assurance processes in European HEIs' and the contribution of their views to improving the quality in higher education. The aim of this article is to address this gap by studying the role of students in internal quality assurance in two institutions across two different national contexts.

We do so by posing the question: "To what extent are students perceived as stakeholders in internal quality processes at different higher education institutions within the framework of the European Standards and Guidelines of Quality Assurance?" Specifically, we are interested how national and internal policies, documents or platforms promote the involvement of students in internal quality assurance processes and how are students involved and influence internal quality assurance procedures at higher education institutions.

In this article we will focus on three of the ESG guidelines ${ }^{1}$ from $2005^{2}$ to study the role of students in internal higher education quality assurance processes:

I. Policy and procedures for quality assurance,

II. Approval, monitoring and periodic review of academic programmes, III. Quality assurance of teaching staff.

To answer our research question we draw on the stakeholder typology developed by Mitchell et al. (1997). Our study comprises a comparison of the role of students in internal quality assurance systems (IQA) in two higher education institutions in two countries, Germany and the Netherlands. The article is structured as follows. After the introduction we introduce the theoretical and methodological underpinnings of this study. Further, we present the findings and a comparison of the two case studies. We conclude with a discussion of our propositions and propose further avenues for research.

\section{Theoretical Framework: Students as Stakeholders in Internal Quality Assurance}

Over the last decades, higher education institutions have undergone a significant transformation towards the managerial model due to an increasing international competition between higher education institutions and the so-called marketization

\footnotetext{
${ }^{1}$ This paper specifically focuses on the investigation of the European Standards and Guidelines for internal quality assurance by neglecting the ESG for external quality assurance and the guidelines for external accreditation agencies.

${ }^{2}$ In this paper we focus on the investigation of the ESG from 2005, despite the latest revision of the (2005) during the ministerial Conference of the Bologna Process in Bucharest (2012), as the impact of the newly revised ESG can hardly be ascertained at this point in time.
} 
of higher education (De Boer and File 2009). This implies that, bit by bit, higher education institutions are being turned into corporate organizations which take into account the opinion of external stakeholders in their strife to compete on higher education quasi-markets (Beerkens 2006; Krücken and Meier 2006; Leisyte and Dee 2012). However, we have limited tools to understand the role of stakeholders, including academics, administrative staff and students in internal decision making processes in such organizations. Therefore, we turn to the stakeholder theory which helps us understand the role of stakeholders in higher education (Beerkens 2006; Jongbloed et al. 2008; Mc Dowell and Sambell 1999). According to Jongbloed et al. (2008) today's higher education institutions have to respond to a number of groups of individuals, with students being the most important stakeholder group at universities. As stated by Haug (2003), in times of growing global higher education competition, the integration of students in institutional decision making and safeguarding their interests have become a necessity to stabilize the influx of new students. Consequently, due to the growing importance of stakeholders for HEIs, it is increasingly expected that HEIs engage with relevant stakeholder groups, as they become accountable, effective and efficient organizations which aim to provide quality higher education (Jongbloed et al. 2008).

We propose that Mitchell et al. (1997) typology of stakeholders' roles in organizations is a useful perspective to understand the complexity of the roles students may play in HEIs internal quality assurance (Leisyte and Westerheijden 2013; Logermann 2014).

Mitchell et al. (1997) use a dynamic identification typology which explains why corporate managers ${ }^{3}$ prioritize certain stakeholder relationships. This typology uses three criteria to create a stakeholder hierarchy: power, legitimacy and urgency. Hereby, power is defined as a party's potential to influence "to the extent that it can gain access to coercive, utilitarian or normative means" (Mitchell et al. 1997, p. 856) to impose its will on the company. Secondly, legitimacy is described as "socially accepted and expected behaviour" (Mitchell et al. 1997, p. 866) which is often coupled with the power to establish actor's authority, but may as well develop independently. Moreover, it describes a party's involvement in important decision making at all levels. Urgency, which adds the dynamic component to the authors' theoretical model, is defined as "the degree to which a stakeholder claims call for immediate attention" (Mitchell et al. 1997, p. 867). Time sensitivity here plays an important role as task related managerial delay is unacceptable to the stakeholder. Urgency also points to the need for stakeholder satisfaction with a specific organizational outcome.

Based on the three criteria of power, legitimacy \& urgency, the authors aim to explain stakeholder salience, whereby salience is defined as "The degree to which managers give priority to competing stakeholder claims" (Mitchell et al. 1997, p. 868). The degree of salience depends on the cumulative addition of the three

\footnotetext{
${ }^{3}$ In the HEI context, managers can be directors of universities, deans of faculties, senate members or directors of institutes.
} 
Fig. 1 Stakeholder categories by Mitchell et al. (1997). Source Own illustration based on Mitchell et al. (1997)
Power Legitimacy Urgency

\begin{tabular}{|c|c|c|c|}
\hline \multicolumn{4}{|l|}{ Latent Stakeholder } \\
\hline Dormant Stakeholder & \multicolumn{3}{|c|}{$\mathrm{x}$} \\
\hline Discretionary Stakeholder & & $\mathrm{x}$ & \\
\hline Demanding Stakeholder & & & $\mathrm{x}$ \\
\hline \multicolumn{4}{|c|}{$\underline{\text { Salient/Expectant stakeholder }}$} \\
\hline Dominant Stakeholder & $\mathrm{x}$ & $\mathrm{x}$ & \\
\hline Dependent Stakeholder & & $\mathrm{x}$ & $\mathrm{x}$ \\
\hline Dangerous Stakeholder & $\mathrm{x}$ & & $\mathrm{x}$ \\
\hline \multicolumn{4}{|l|}{$\underline{\text { Definitive stakeholder }}$} \\
\hline Definitive Stakeholder & $\mathrm{x}$ & $\mathrm{x}$ & $\mathrm{x}$ \\
\hline
\end{tabular}

criteria (attributes). Based on the presence or absence of certain attributes, (Mitchell et al. 1997) distinguish between three major stakeholder types which have a number of sub-types. Figure 1 provides an overview of these types which depend on which combination of the attributes they possess if any.

When applying Mitchell et al.'s (1997) stakeholder typology to our research context, we specifically turn to the degree of students' salience as stakeholders in HEIs' internal quality assurance processes. Formally, students can be assigned to any of the sub types, such as, Dormant, Discretionary, Demanding, Dominant, Dependent, Dangerous and Definitive Stakeholders based on how much power, legitimacy and urgency they have as students in the organizational matters regarding internal quality assurance.

Students' power may be manifested in their potential to ask for changes in study programmes, courses or HEIs' internal quality assurance processes. Their power potential then may be manifested in the change of the structure or content of a course or programme.

Students' legitimacy can be observed through their representation in internal quality assurance bodies and the transparency of IQA procedures to students. The ESG specifically highlight students' legitimate involvement in IQA processes, so we find this attribute especially important for the current study, (ENQA 2009). Finally, students' urgency is operationalized as students' claims for higher quality of courses and study materials. This attribute is again present in the ESG guidelines as students should be able to demand quality higher education (ENQA 2008, 2009, 2011). 
Based on the above (Mitchell et al. 1997) typology, we put forward three propositions regarding students' salience as stakeholders:

- "If students are perceived as Definitive ${ }^{4}$ Stakeholders, students have an influence on internal quality assurance processes in the HE institution".

- "If students are perceived as Salient/Expectant $t^{5}$ Stakeholders, students have a limited influence on internal quality assurance processes in the HE institution".

- "If students are perceived as Latent ${ }^{6}$ Stakeholders, students have no influence on internal quality assurance processes in the HE institution".

Following the ESG, students are perceived as Definitive stakeholders in HEIs' internal quality assurance processes, including all steps of the internal quality assurance cycle. This implies their active involvement in course evaluations, programme reviews or the participation in and contribution to internal QA boards and committees.

\section{Research Design and Methodology}

A comparative case study was conducted to answer the main research question (Schnell et al. 2011). The units of analysis of this study are European higher education institutions in different Bologna countries, while the units of observation are departments of European higher education institutions. To select the units of analysis we chose for the non-probability sampling approach of extreme case sampling, as "concepts are often defined by their extremes, that is, their ideal types (Gerring 2004, p. 101)”. Specifically, we selected one German and one Dutch HEI, as these countries have adopted the ESG to a different degree, with the Netherlands being perceived as a forerunner, "fully matching the ESG model (ESU 2009, p. 57)", while German HEIs are seen having less focus on the ESG in the HEIs as "Student unions expressed their concerns regarding the internal quality assurance systems in Germany (ESU 2009, p. 57)".

The units of observation were chosen purposively focusing on the smallest entity to which internal quality assurance process is delegated at both studied HEIs. Hereby, we selected two units in similar academic disciplines which have similar number of students. For the Dutch case study, a Faculty offering Economic, Political and Social Sciences, with a student population of around 2200 students, was selected. For the German case study, a German Faculty Institute offering similar degrees to around 1600 students was selected. The German Institute belongs

\footnotetext{
${ }^{4}$ Definitive Stakeholders direct over all three attributes of power, legitimacy and urgency and thus enjoy highest salience, meaning that ultimate priority is given to the interests of such stakeholders. ${ }^{5}$ Stakeholders of this group decree over two of the three relevant attributes and thus enjoy a medium degree of salience (see Fig. 1).

${ }^{6}$ Stakeholders from this class are only in the possession of one of the three fundamental attributes. From the management perspective, influence and salience of this stakeholder group is rather low.
} 
to the Faculty of Educational and Social Sciences and is the smallest entity to which the responsibility for internal quality assurance is delegated at the HEI.

\subsection{Data Collection}

The data collection consisted of desk research, analysing national and institutional policy documents on internal quality assurance. Moreover eight semi-structured interviews (four at each institution) with academic staff, quality assurance officers and the student association were conducted. To better depict the student opinion on the institutions' internal quality assurance systems, a student survey with 93 respondents from the Dutch Institute and 83 respondents from the German Institute was undertaken (see Table 1).

Different data sets were used to depict the institutional and student views regarding the students' role in internal quality assurance processes. By comparing and triangulating this data we aimed to interpret to what extent students were participating in the internal quality assurance processes as stakeholders and how salient they were.

\subsection{Data Analysis}

To operationalize the ESG guidelines pertaining to student involvement in the internal quality assurance process, we focus on the participation of students as equal partners in major internal quality assurance bodies and procedures in HEIs (ESG, Policy and Procedures for quality assurance). To understand if students participate in approval, monitoring and periodic review of study programmes, we focus on the voice of students in HEIs. Concerning the guidelines for the quality assurance of teaching staff, we will study what role do students' evaluations of academic staff teaching play, what instruments are used for this purpose and how they are used.

For the data analysis of desk research, qualitative content analysis was employed (Babbie 2006). For the analysis of semi-structured interviews, a deductive coding scheme was used, following the qualitative content analysis approach by Mayring (2010). We coded the interviews looking for the attributes of power, legitimacy and urgency (Mitchell et al. 1997) which are aligned to the three studied ESG guidelines.

For the analysis of the survey data, questions were grouped into sections which contributed to understand power, legitimacy and urgency of students as stakeholders in the studied institutions. The survey questions were constructed based on the NSS survey. ${ }^{7}$

\footnotetext{
${ }^{7}$ The National Student Survey is yearly launched in the UK to investigate students' satisfaction with their study programmes and teaching quality.
} 
Table 1 Instruments of data collection

\begin{tabular}{|c|c|c|}
\hline Desk research & Semi-structured interviews & Student survey \\
\hline $\begin{array}{l}\text { - National and institutional } \\
\text { documents on internal } \\
\text { quality assurances (national } \\
\text { HE legacy, central HEI } \\
\text { management documents or } \\
\text { institutional quality statutes) } \\
\text { Webpages, books, scientific } \\
\text { articles }\end{array}$ & $\begin{array}{l}6 \text { face to face interviews } \\
\text { with internal quality } \\
\text { assurance staff at both HE } \\
\text { institutions ( } 3 \text { at the Dutch } \\
\text { Faculty and } 3 \text { at the German } \\
\text { Institute) } \\
\text { Interviewees: Internal } \\
\text { quality assurance officer, } \\
\text { Internal Quality Assurance } \\
\text { Staff, Professors } \\
2 \text { face to face interviews } \\
\text { with student associations at } \\
\text { both studied HE institutions }\end{array}$ & $\begin{array}{l}176 \text { students of all } \\
\text { disciplines at both studied } \\
\text { HE institutions } \\
93 \text { students from the Dutch } \\
\text { and } 83 \text { of the German } \\
\text { Institute } \\
\text { Dutch Faculty: } 50 \% \text { of } \\
\text { respondent were female, } 30 \\
\text { male and } 20 \% \text { are unknown. } \\
\text { The average age of } \\
\text { respondents was } 23 \text { and } \\
\text { respondents were enrolled in } \\
19 \text { different study } \\
\text { programmes } \\
\text { German Institute: } 66 \% \text { of } \\
\text { respondents were female and } \\
34 \text { were male. The average } \\
\text { age of respondents was } 22 \\
\text { and respondents were } \\
\text { enrolled in } 14 \text { different study } \\
\text { programmes }\end{array}$ \\
\hline
\end{tabular}

\section{Students' Role in the Studied Dutch Faculty}

In the following, students' stakeholder position at the investigated Dutch Faculty is determined following the stakeholder typology of Mitchell et al. (1997) and by triangulating the collected data from the institutional documents and semi-structured interviews, and the student survey (see Table 2). Findings from the collected data show that in the Dutch Faculty students are regarded as weak Definitive stakeholders within the Faculty's IQA processes.

When combining the insights coming from different sources on students' salience as stakeholders we observed that students had a rather sceptical estimation of their power and influence potential on the Faculty's IQA processes. Nevertheless, despite such self-perception of students, their power was asserted as noted in the interviews with academic and administrative staff and as noted in the institutional documents. They have asserted that students' feedback leads to frequent changes in the curricula of study programmes and courses.

In terms of urgency, students and academics jointly confirmed that students have urgent claims to safeguard the quality of higher education. Regarding legitimacy, both parties acknowledge that students are vital and legitimacy partners in internal quality assurance process (Faculty Regulation 2010). In addition, the non-transparency of internal quality measures and the non-communication of implemented measures to students are jointly criticized by students and academic staff. This limits students' ability to follow up if their feedback is taken into 
Table 2 Students as stakeholder in the Dutch faculty

\begin{tabular}{|c|c|c|c|}
\hline & $\begin{array}{l}\text { Desk research } \\
\text { (institutional view) }\end{array}$ & $\begin{array}{l}\text { Semi-structured } \\
\text { interviews (institutional } \\
\text { view) }\end{array}$ & $\begin{array}{l}\text { Survey (student } \\
\text { opinion and student } \\
\text { association) }\end{array}$ \\
\hline Power & $\begin{array}{l}\text { Programme Director } \\
\text { has to react on student } \\
\text { feedback } \\
\text { Internal check-up } \\
\text { system } \\
\text { Institution wants to } \\
\text { meet students' needs to } \\
\text { retain number of } \\
\text { enrolled students }\end{array}$ & $\begin{array}{l}\text { Students have power: } \\
\text { Frequent changes to } \\
\text { courses and study } \\
\text { programme based on } \\
\text { student feedback } \\
\text { Influence on teachers' } \\
\text { promotion potential }\end{array}$ & $\begin{array}{l}\text { - Limited power } \\
\text { (Students do not know } \\
\text { if their feedback has an } \\
\text { influence on the } \\
\text { quality of education or } \\
\text { have a low estimation } \\
\text { of their power } \\
\text { potential) }\end{array}$ \\
\hline Legitimacy & $\begin{array}{l}\text { - Integration of students } \\
\text { in all major internal } \\
\text { quality assurance } \\
\text { bodies (Faculty } \\
\text { Regulation 2010) }\end{array}$ & $\begin{array}{l}\text { - Students legitimate } \\
\text { partners in all major } \\
\text { internal quality } \\
\text { assurance bodies-lack } \\
\text { of transparency } \\
\text { regarding feedback } \\
\text { implementation }\end{array}$ & $\begin{array}{l}\text { - Legitimate partners } \\
\text { in all major internal } \\
\text { quality assurance } \\
\text { bodies } \\
\text { - Lack of transparency } \\
\text { regarding feedback } \\
\text { implementation }\end{array}$ \\
\hline Urgency & $\begin{array}{l}\text { - Possibility of } \\
\text { complaints via Student } \\
\text { Association and } \\
\text { Examination } \\
\text { Committee }\end{array}$ & $\begin{array}{l}\text { - Students have urgent } \\
\text { claims (fast } \\
\text { participation in quality } \\
\text { evaluation instruments) }\end{array}$ & $\begin{array}{l}\text { - Safeguarding of the } \\
\text { quality of education } \\
\text { and teaching is } \\
\text { important }\end{array}$ \\
\hline
\end{tabular}

Source Desk research, semi-structured interviews and student survey (2013)

account. This points to weaker stakeholder position. We thus conclude that in this regard student's legitimacy position is limited (see Fig. 2). Overall, it can be concluded that students are weak Definitive Stakeholders in the Dutch Faculty's IQA processes (see Fig. 2).

In this case study we have seen that students have power and their claims have urgency. At the same time students' legitimacy is limited as even though the student feedback is taken into consideration, this is not evident to students and is not made transparent. This lack of transparency, which is confirmed by both parties, leads to a limitation of students' legitimacy position within the internal quality assurance system. At the same time, given their representation in all major internal quality assurance committees they have strong power and urgency. Still their limited legitimacy points out that they are not perceived as Definitive Stakeholders in the Dutch case study context.

\subsection{Students' Role in the Studied German Institute}

In the following, students' stakeholder position at the investigated German Institute is determined according to the stakeholder typology of Mitchell et al. (1997). 


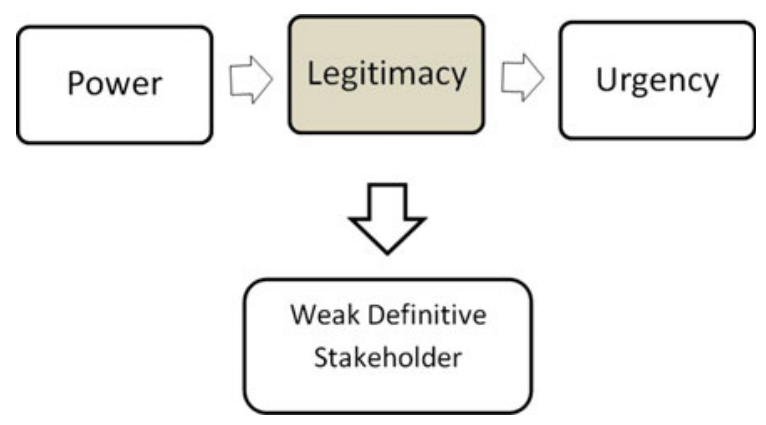

Fig. 2 Students as stakeholders in the Dutch Faculty. Source Desk Research, Semi-Structured Interviews and Student Survey (2013)

Findings from the collected data (Table 3) show that students are perceived as weak Dependent Stakeholders in the German Faculty's IQA processes.

When combining the insights from different data sources we observe that both students and interviewed staff confirm that students' power potential within the IQA system is rather limited. Both parties note that the consideration of students' feedback heavily dependents on the voluntary cooperation of each individual lecturer as there are no sanctioning mechanisms for poor performance in the Institute's IQA procedures. The feedback from students is not necessarily taken into account. Thus, students have a low power potential within the Institute's IQA processes.

Concerning legitimacy, both students and staff assert that student association representatives are well integrated in all major internal quality assurance bodies, though their legitimacy status is limited as their numbers in these committees are low. This implies that students' claims can be easily neglected, if not supported by other committee members. Students also criticized the non-transparency of the current internal quality procedures, which prevent a sophisticated dissemination of evaluation results to students. Thus, students' limited legitimacy is underscored. Concerning urgency, students are reported to have a strong interest in the safeguarding of quality of their courses.

To summarize, students at the German Institute can be characterized as weak Dependent Stakeholders. Although they have urgency, they are not equally represented in IQA procedures, they have limited legitimacy and have limited power potential. This implies that students are not able to pursue their interests within the Institute's IQA settings in a major way (see Fig. 3). 
Table 3 Students as stakeholders in the German Institute

\begin{tabular}{|c|c|c|c|}
\hline & $\begin{array}{l}\text { Desk research } \\
\text { (institutional view) }\end{array}$ & $\begin{array}{l}\text { Semi-structured } \\
\text { interviews (institutional } \\
\text { view) }\end{array}$ & $\begin{array}{l}\text { Survey (student } \\
\text { opinion and students } \\
\text { association) }\end{array}$ \\
\hline Power & $\begin{array}{l}\text { - Results of student } \\
\text { evaluation should be } \\
\text { considered by teachers } \\
\text { and used for quality } \\
\text { improvements } \\
\text { (Evaluation statute, } \\
\text { 2005) }\end{array}$ & $\begin{array}{l}\text { - Limited power: Student } \\
\text { feedback may lead to } \\
\text { changes but only if } \\
\text { voluntarily considered } \\
\text { by teachers } \\
\text { - Missing sanctioning } \\
\text { system to follow-up on } \\
\text { implementation of } \\
\text { students' feedback }\end{array}$ & $\begin{array}{l}\text { - Low power } \\
\text { estimation } \\
\text { - Students do not } \\
\text { know if/how } \\
\text { feedback is } \\
\text { implemented } \\
\text { - Students' claims are } \\
\text { often neglected }\end{array}$ \\
\hline Legitimacy & $\begin{array}{l}\text { - One representative of } \\
\text { student association } \\
\text { integrated in all major } \\
\text { internal quality } \\
\text { assurance bodies }\end{array}$ & $\begin{array}{l}\text { - Legitimate due to } \\
\text { integration of members } \\
\text { of student association } \\
\text { - Limited Legitimacy: } \\
\text { High dependency due to } \\
\text { underrepresentation }\end{array}$ & $\begin{array}{l}\text { - Perceive themselves } \\
\text { as underrepresented } \\
\text { in internal quality } \\
\text { assurance procedures } \\
\text { - Criticize non } \\
\text { transparency of IQA } \\
\text { measures }\end{array}$ \\
\hline Urgency & $\begin{array}{l}\text { - Institute offers } \\
\text { students channels to } \\
\text { communicate their } \\
\text { needs }\end{array}$ & $\begin{array}{l}\text { - Students have urgent } \\
\text { claims (curricula or } \\
\text { counselling situation) }\end{array}$ & $\begin{array}{l}\text { - Safeguarding of the } \\
\text { quality of education } \\
\text { and teaching is } \\
\text { important }\end{array}$ \\
\hline
\end{tabular}

Source Desk research, semi-structured interviews and student survey (2013)

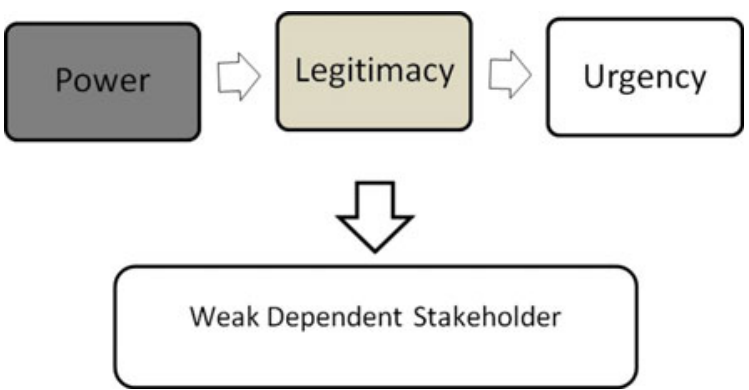

Fig. 3 Students as Stakeholder in the German Institute. Source Desk research, semi-structured interviews and student survey (2013)

\section{Discussion}

Both case studies demonstrated that students are regarded as stakeholders in studied HEIs in the Dutch and in the German contexts. At the same time, the extent of their salience as stakeholders differs between the two studied HE institutions to a large extent. 
Overall, students at the Dutch Faculty enjoy a significantly higher degree of stakeholder salience than students in the German Institute. Table 4 provides below shows what categories of student stakeholders we found in our two case studies. In the Dutch case we mainly found students to be weak Definitive Stakeholder, while students in the German Institute could be categorized as weak Dependent Stakeholders.

As shown in Chapter "Redefining Internationalization at Home", students at the Dutch Faculty have a quite substantial influence on internal quality assurance processes and they can be defined as weak Definitive Stakeholders, which confirms our first proposition.

In line with Mitchell et al. (1997), students' influence the Dutch Faculty's internal quality assurance processes as manifested in students' power position, limited legitimacy status and urgency of their claims (see Table 7). Though students at the Dutch Faculty were not well aware of their power potential, their participation in course evaluations and contribution to panel talks acted as strong sources of students' power. Results of semi-structured interviews and document analysis showed that academics are under pressure to consider student course evaluations and address the raised issues by the students (I2(a); I3(a) 2013). Thus, students' feedback influences the quality of teaching at the Faculty, though students' are not aware of this and their influence potential. These findings are also in line with the findings of Leisyte et al. (2013), stating that students at Dutch HEIs have power in internal quality assurance processes.

In the Dutch case study, students' power is strongly fostered by the Dutch Faculty's internal monitoring and sanctioning tools for quality assurance. Students' power is supported by students' urgent claims and by demanding the constant improvement of quality of teaching. Concerning students' representation in the Dutch Faculty's internal quality assurance processes, students are represented in equal number in all internal quality assurance bodies. This fosters students' legitimacy status and strengthens their influence on internal quality assurance. Nevertheless, the limited transparency of the IQA procedures limits students' legitimacy status, as students are not aware if their feedback is implemented by the Faculty. As according to Leisyte et al. (2013): "The student ... misses feedback about follow-up, although clear procedures for course evaluation via student surveys are in place" (Leisyte et al. 2013, p. 5). This shortcoming limits students' legitimacy position and thus, their influence potential (Leisyte et al. 2013).

Table 4 Students' Stakeholder Positions

\begin{tabular}{l|l|l|l}
\hline Institution & $\begin{array}{l}\text { Latent } \\
\text { stakeholder }\end{array}$ & Expectant stakeholder & Definitive stakeholder \\
\hline $\begin{array}{l}\text { Dutch } \\
\text { faculty }\end{array}$ & & & $\begin{array}{l}\text { Power, Urgency, } \\
\text { (Weak Legitimacy) }\end{array}$ \\
\hline $\begin{array}{l}\text { German } \\
\text { Institute }\end{array}$ & & $\begin{array}{l}\text { Urgency, (Weak Legitimacy) } \\
\text { Dependent Stakeholders } \rightarrow\end{array}$ & \\
\hline
\end{tabular}

Source Desk research, Semi-structured interviews and student survey (2013) 
Students' limited legitimacy position allows us to characterise them as weak Definitive Stakeholders, despite students' formal power position and their ability to put forward urgent claims.

In contrast to the Dutch case study, students in the German Institute have limited influence on IQA processes, which also results in their lower stakeholders' position as weak Dependent Stakeholders (Table 4), which confirms our second proposition.

In line with Mitchell et al. (1997), the studied German students' are Dependent stakeholders because of their low power potential, their limited legitimacy status and students' strong urgent claims (see Table 4). All data sources from the German case study confirm students' rather low influence potential, as students' feedback solely serves as an additional source of information on which basis the academics may voluntarily improve the quality of a particular course. Thus, students' influence on quality improvement in the German case is lower than in the Dutch case study, as there is no follow-up system, which would oblige academics to consider students' feedback. Overall, the German Institute's IQA set-up weakens students' influence potential, while the Dutch IQA strengthened students' power.

Further, the high student numbers at the German Institute also limited their power, as the Institute is not under great pressure to meet students' urgent claims. Their limited influence potential in the German case study comes from their limited legitimacy. Though student representatives are formally involved in all internal quality assurance bodies, they are mostly underrepresented in all committees. Thus, students' input regarding the IQA can be described as tokenistic, which means that despite students' formal representation they are not able to put forward significant changes in internal quality assurance in the institution. Moreover, as in the Dutch case, students also criticize the great non-transparency of the IQA procedures, which do not foresee a follow-up on course evaluation results and thereby limit their legitimacy status. Due to all these factors, we observe students' limited legitimacy position in the IQA procedures in the German case and characterize them as weak Dependent Stakeholders.

When comparing the findings of both case studies it can be concluded that each of the two investigated HE institutions predominantly complies with the ESG guidelines, even though we can find variability in the role of students in internal quality assurance in the two studies HEIs. Still, some differences regarding HEIs' consideration of the ESG can be noted. In the following, the Dutch Faculty's and the German Institute's consideration of the three investigated ESG guidelines is depicted (see Table 5).

As shown in Table 5, regarding the ESG guideline of policy and procedures for quality assurance, both $\mathrm{HE}$ institutions follow central or internal quality assurance policies, which urge the regular quality evaluation of teaching in HEIs. The studied Dutch Faculty mainly follows its own internal Faculty evaluations provisions, which are in line with general University quality assurance policies and national HE legacies, while the German Institute predominately implements central IQA assurance guidelines, set by the central University management. In both cases, documents and provisions demand the active involvement of students in IQA processes and their integration in internal quality assurance bodies which, according 
Table 5 HEIs' conformity with the ESG

\begin{tabular}{l|l|l|l}
\hline Institution & $\begin{array}{l}\text { Policy and } \\
\text { procedures for } \\
\text { quality assurance }\end{array}$ & $\begin{array}{l}\text { Approval, monitoring and } \\
\text { periodic review of academic } \\
\text { programmes }\end{array}$ & $\begin{array}{l}\text { Quality } \\
\text { assurance of } \\
\text { teaching staff }\end{array}$ \\
\hline $\begin{array}{l}\text { Dutch } \\
\text { faculty }\end{array}$ & Fulfilled & Fulfilled & Fulfilled \\
\hline $\begin{array}{l}\text { German } \\
\text { Institute }\end{array}$ & Minor shortcomings & Shortcomings & Fulfilled \\
\hline
\end{tabular}

Source Desk research, semi-structured interviews and student survey (2013)

to Leisyte et al. (2013), ascertains students' important positioning as stakeholders in quality assurance. In the Dutch case study, internal provisions regarding student involvement are quite precise, which leads to a predominantly equal representation of students within internal quality assurance committees. In contrast, the regulations of the German Institute are rather vague when it comes to student representation, which leads to a frequent underrepresentation of students within IQA bodies. Thus, concerning student involvement, the Dutch Faculty complies with this ESG guideline to a higher extent.

Concerning the ESG guideline for the approval, monitoring and periodic review of academic programmes, it can be concluded that studied HE institutions employ comprehensive quality assurance instruments to assure the regular evaluation of quality standards, by integrating students in such processes. Hereby, student course evaluations constitute the main instruments of internal quality assurance at both studied HE institutions. Still, the Dutch Faculty's IQA is marked by a stricter monitoring procedure, which strengthens students' influence potential (I2(b) 2013; I3(b) 2013). On the contrary, the German Institute's ambiguity in regulation weakens students' influence potential. The Institute's soft approach might strive from Germany's general HE culture, in which academic freedom and academic autonomy are predominant values (Westerheijden and Kohoutek 2013). Thus, in line with Westerheijden and Kohoutek (2013), in the German case, the local culture and regulation seem to hamper the full consideration of the ESG. Again, the Dutch Faculty's involvement of students is more in line with the ESG criteria regarding this particular guideline.

Relating to the ESG criteria of quality assurance for teaching staff, both studied HE institutions evaluate the teaching abilities of lecturers via student evaluations. Thus, both HE institutions involve students in these processes as recommended by the ESG guidelines. Still, the influence of Dutch students on the quality of teaching seems to be higher than that of students in the German Institute.

To conclude, both studied HE institutions are largely in line with the investigated ESG guidelines regarding the role of students in internal quality assurance in HEIs, although the studied units consider the ESG rather unconsciously. At both HE institutions, the ESG were rather unknown, as seen from interviews with academic staff and noted from the document analysis. HEI's rather unconscious compliance with the ESG standards has also already been considered in previous studies, such 
as by the IBAR project (2013) and Rattray et al. (2013), stating that compliance with the ESG is rather "process-led", with the institutional logics and organizational dynamics serving as key requirement for a HE institution's fulfilment of the ESG. Thus, students' stakeholder position does not seem to be related to HE institutions' consideration of the ESG, but seem to rather depend on national or institutional internal quality assurance policies and culture.

\section{Conclusion}

The aim of this study was to understand students' role within HEIs' internal quality assurance processes.

Findings of the comparative case study show that both investigated European HE institutions use internal quality assurance documents which promote the active integration of students in internal quality assurance processes. Thus, at both studied institutions, the involvement of students in internal quality assurance processes is required by internal policies and documents, though provisions are more specific for the Dutch Faculty, than for the German Institute.

Regarding students' active involvement in HEIs' internal quality assurance processes, both case studies demonstrated that student course evaluations constitute the main instrument of student engagement in internal quality assurance. However, the influence of student course evaluations differs between the two investigated institutions, as at the Dutch Faculty evaluation results are taken more seriously (I2 (a) 2013; I3(a) 2013). The German Institute's soft policy approach, in which lecturers may consider evaluation results on a voluntary basis, weakens students' influence potential. Moreover, in both cases, student associations play a big role in representing students' quality claims in internal quality procedures and internal quality assurance committees. One shortcoming regarding students' involvement in the IQA procedures was ascertained in both cases studies, namely, the missing re-communication of quality improvements to students. This implies that even though students are actively integrated in internal quality procedures, they are not informed about their influence on internal quality assurance and the implementation of their feedback.

The findings of the document analysis and interviews with academic staff also showed that national policy documents may also have an influence on the involvement of students in internal quality assurance processes at higher education institutions. The design and governance of national quality assurance system in Europe can differ. Hereby, the Netherlands show a more managerially driven tradition in HE quality assurance, while the 1 German system seems to have a decentralized approach towards quality assurance practices.

In both case studies, national legislation promotes active engagement of students in internal quality assurance procedures. Still, findings show that the main responsibility of student engagement is delegated to each individual higher education institution. Thus, in line with (Ursin et al. 2008) the role of students highly 
depends on the active engagement of students at each individual HE institution (Leisyte et al. 2013).

The findings of the two cases also showed that both case studies involved students in policy and procedures for quality assurance At the same time students and academic staff were not aware of the ESG. Direct links to the ESG are seldom found in internal quality assurance documents. Thus, in line with Westerheijden et al. (2013), the visible influence of the ESG on HEIs' internal quality procedures and student involvement therein are rather absent. The consideration of the ESG and student involvement seem to strive foremost from an institution's general organizational setting and the established quality culture, which implies that "the local implementation and translation" is crucial for the consideration of the ESG criteria (Westerheijden and Kohoutek 2013). This also indicates that, due the soft policy character of the ESG, a successful application of the ESG principles to a large extent depends on HEIs' voluntary consideration of ESG.

Thus, the ESG cannot be defined as a policy framework for fostering students' stakeholder roles in IQA, as the ESG of 2005 more or less codify "what had already become practice through earlier quality assurance schemes" at the institutions (Schwarz and Westerheijden 2004). Thus, students' integration as stakeholders in IQA does not dependent on HEI's consideration of the ESG, but seems to depend on an institution's quality assurance polices and the prevailing quality assurance culture. Still in this study, an institution's greater conformity with the ESG also comes with a stronger role of students in IQA. In this study, the Dutch Faculty's internal quality assurance system was more in line with the ESG guidelines, and students enjoy a rather strong stakeholder position as weak Definitive Stakeholders. The German Institute's conformity to the ESG provisions was lower, with students playing a less stronger role in IQA and therefore defined as weak Dependent Stakeholders, whose power potential is low and whose legitimacy status is limited by students' high dependency on academic staff to realize their claims.

Overall, the study showed that students are involved as stakeholders in HEIs' internal quality assurance processes, though their actual power and influence potential in their role as stakeholders differs from institution to institution. This implies that the ESG's influence on students' position in institutional IQA processes is rather absent. Therefore, this study recommends the establishment of follow-up measures in HE institutions' internal quality assurance processes to ensure that students' feedback is taken into account when improving courses and study programmes. Moreover, in order to secure student participation in IQA, HEIs have to inform students' more thoroughly about what happens with their course evaluations and what changes will be made as a result. Otherwise, students could lose their interest in participating in internal quality assurance procedures as "students' participation in quality assurance processes requires transparent procedures and visible results for students" (Popović 2001, p. 6).

Open Access This chapter is distributed under the terms of the Creative Commons Attribution Noncommercial License, which permits any noncommercial use, distribution, and reproduction in any medium, provided the original author(s) and source are credited. 


\section{References}

Babbie, E. (2006). The Practice of Social Research. Cengage Learning Service.

Beerkens, E. (2006). University Policies for the Knowledge Society: Global Standardization, Local Re-Inventions. Paper presented at the Conference of the International Sociological Association, South Africa. http://www.beerkens.info/files/Beerkens_UPKS_ISA_2006.pdf

Corbett, A. (2003). Ideas, institutions and policy entrepreneurs: towards a new history of higher education in the European Community. European Journal of Education, 38(3), 315-330.

De Boer, H., \& File, J. (2009). Higher Education Governance Reforms Across Europe. Retrieved from http://www.utwente.nl/mb/cheps/publications/publications $\% 202009 / \mathrm{c} 9 \mathrm{hdb} 101 \%$ 20modern\%20project\%20report.pdf

ENQA (2008). Quality Procedures in the European Higher Education Area and Beyond-Second ENQA. Retrieved 13th of November, 2012 from http://www.enqa.eu/pubs_occasional.lasso

ENQA. (2009). Standards and Guidelines for Quality Assurance in the European Higher Education Area. Retrieved from http://www.enqa.eu/files/ESG_3edition\%20\%282\%29.pdf

ENQA (2011). Mapping the implementation and application of the ESG (MAP-ESG Project). Final report of the project steering group. Retrieved 14th of November, 2012 from http://www. enqa.eu/files/op_17_web.pdf

ESU (2009). Bologna with Student Eyes. Retrieved from http://www.ond.vlaanderen.be/ hogeronderwijs/bologna/conference/documents/BolognaWithStudentEyes2009.pdf

ESU (2010). Bologna at the finish line. An account of ten years of European Higher Education reform. Retrieved from http://www.ond.vlaanderen.be/hogeronderwijs/bologna/2010_conference/documents/BAFL_online.pdf

Evaluation Statute (2005). Internal Evaluation Statute of German Institute.

Faculty Regulation (2010). Dutch Faculty.

Gerring, L. (2004). What is a case study and what is it good for? American Political Science Review, 98(2), 341-352.

Haug, G. (2003). Quality assurance/accreditation in the emerging european higher education area: a possible scenario for the future. European Journal of Education, 38(3), 229-240.

Hounsell, D. (2007). Towards more sustainable feedback to students. London: Routledge.

IBAR Project (2013). Identifying barriers in promoting European Standards and Guidelines for Quality Assurance at institutional level. Retrieved from http://www.ibar-llp.eu/project.html

Interview I2(a), (2013). Quality Assurance Officer (Dutch Faculty).

Interview I2(b), (2013). Quality Assurance Officer (German Institute).

Interview I3(a), (2013). Professor (Dutch Faculty).

Interview I3(b), (2013). Professor (German Institute).

Jongbloed, B., Enders, J., \& Salerno, C. (2008). Higher education and its communities: Interconnections, interdependencies and a research agenda. Journal of Higher Education, 56 (3), 303-324. doi:10.1007/s10734-008-9128-2

Keeling, R. (2006). The Bologna process and the Lisbon Research Agenda: The European Commission's expanding role in higher education discourse. European Journal of Education, 41(2), 203-223.

Klemenic, M. (2012). The changing conceptions of student participation in HE governance in the EHEA. Springer.

Kohoutek, J., Land, R., \& Owen, C. (2013). Identifying barriers in promoting the European Standards and Guidelines for Quality Assurance at institutional level (IBAR) Final Synthesis Report IBAR Project Retrieved from http://www.ibar-llp.eu/assets/files/Results/Final_ synthesis_report.pdf

Krücken, G., \& Meier, F. (2006). Globalization and Organization-Turning the University into an Organizational Actor. Oxford University Press.

Leisyte, L. \& Dee, J. (2012). Understanding academic work in a changing institutional environment. Faculty autonomy, productivity and identity in Europe and the United States. In: 
Smart, John C.; Paulsen, M. (eds.): Higher Education: Handbook of Theory and Research, Vol. 27. Dordrecht: Springer, pp. 123-206.

Leisyte, L., \& Westerheijden, F. (2013). Stakeholders and Quality Assurance in Higher Education. Paper presented at the 26th Annual CHER conference, Lausane.

Leisyte, L., Epping, E., \& Faber, M. (2013). IBAR WP11: The National study (Information and Quality). CHEPS, The Netherlands: University Twente.

Lisbon Strategy (2009). Lisbon European Council 23 and 24 March 2000 Presidency Conclusion. Retrieved from http://www.europarl.europa.eu/summits/lis1_en.htm

Logermann, F. (2014). The ESG and their impact on students as stakeholders at European higher education institutions. A comparative study of Germany and the Netherlands. MSc thesis, University of Twente, University of Münster.

Mayring, P. (2010). Qualitative Inhaltsanalyse. Grundlagen und Techniken. Weinheim: Beltz Verlag.

Mc Dowell, L., \& Sambell, K. (1999). Fitness for purpose in the assessment of learning: students as stakeholders. Quality in Higher Education, 5(2), 107-123.

Mitchell, R. K., Agle, B. R., \& Wood, D. J. (1997). Toward a theory of stakeholder identification and salience: defining the principle of who and what really counts. Academy of Management Review, 22(4), 853-866.

Murray, H. G. (1997). Does evaluation of teaching lead to improvement of teaching? International Journal for Academic Development, 2(1), 8-23.

Popović, M. (2001). General report Student Participation in Higher Education Governance. Aghveran, Armenia.

Rattray, J. et al. (2013). A winding stair: implementing and establishing a common framework for $Q A$ in European higher education. Durham University.

Schwarz, S., \& Westerheijden, D. F. (2004) Accreditation in the Framework of Evaluation Activities: A Comparative Study in the European Higher Education Area. In: Accreditation and Evaluation in the European Higher Education Area. Higher Education Dynamics, Vol. 5. Springer, Berlin, pp. 1-41.

Schnell, R., Hill, P., \& Esser, E. (2011). Methoden der empirischen Sozialforschung. Oldenbourg Verlag.

Ursin, et al. (2008). Evaluation and quality assurance in Finnish and Italian Universities in the Bologna Process. Quality in Higher Education, 14(2), 109-120.

Westerheijden, D. F., \& Kohoutek, J. (2013). Working together to take quality forward. Paper presented at the 8th European Quality Assurance Forum, The Netherlands CHEPS \& Czech Republic Centre for Higher Education Studies.

Westerheijden, D.F., Epping, E., Faber,M., Leisyte, L. \& Weert, E. de (2013). Comparative IBAR Report WP9: Stakeholders in Higher Education. The Netherlands, University Twente: CHEPS. 